\title{
Review Article \\ Technological Advancement and the Economic Benefit of Indonesian Rain-Fed Farming Development
}

\author{
A. A. Sulaiman, ${ }^{1}$ A. Candradijaya $(1)^{2}{ }^{2}$ and M. Syakir ${ }^{3}$ \\ ${ }^{1}$ Faculty of Agriculture, University of Hasanuddin, Makassar, Indonesia \\ ${ }^{2}$ Bureau of International Cooperation, Ministry of Agriculture, Jakarta, Indonesia \\ ${ }^{3}$ IAARD, Ministry of Agriculture, Jakarta, Indonesia
}

Correspondence should be addressed to A. Candradijaya; a.candradijaya@gmail.com

Received 14 January 2019; Revised 13 March 2019; Accepted 4 April 2019; Published 2 May 2019

Academic Editor: Othmane Merah

Copyright (C) 2019 A. A. Sulaiman et al. This is an open access article distributed under the Creative Commons Attribution License, which permits unrestricted use, distribution, and reproduction in any medium, provided the original work is properly cited.

\begin{abstract}
The contribution of rain-fed farming to national food production in Indonesia has yet to be optimal. The major constraint has been limited water supply, where it relies exclusively on the rainfall, and hence its planting index (PI) is still low, on average only 1.05 . The establishment of water management system to support rain-fed fields with the introduction of suitable cultivation techniques (gogo rancah, walik jerami, super jarwo, and ratoon paddy) is known to be effective in rain-fed farming. Further, the use of droughttolerant paddy variety and changing cropping pattern to focus on paddy, maize, and soybean would potentially improve the food production capacity in Indonesia. This study has shown these interventions, when applied to the existing 4 million ha rain-fed fields, are estimated to increase annual rice production by 16.7 million tons. The production of maize and soybean is also expected to increase by 3.7 million tons and 0.98 million tons per year, respectively. It is beyond the scope of this study, however, to consider the actual benefit felt by rain-fed smallholder farmers. Future research with farmers as its focus and the capacity of Indonesian institutions toward rain-fed farming thus will contribute further to the rain-fed farming development in Indonesia. This article shares a strategy in maximising the contribution of the currently available 4 million hectares of rain-fed land to the national food production, and hence sustainable food self-sufficiency in Indonesia.
\end{abstract}

\section{Introduction}

To feed the burgeoning world community of 9.73 billion people by 2050 , additional food will have to be produced to at least $70 \%$ of total current production [1]. As the fourth world's largest population and agriculture-based country, Indonesia's current availability of agricultural land resources is ascertained not to be sufficient to fulfill the forecasted demand for food, especially rice as the main staple food, for its people which is expected to reach 321 million people by 2050 (to illustrate, one ha of paddy fields in Indonesia must support the lives of 33 people, while in other countries it is only to feed 2-3 people, or at most 10 people (Sulaiman, et al., pp. 6)) [2]. Notwithstanding, rising incomes will consequently cause dietary change for many Indonesians, and the level of rice per capita consumption in recent years has only slowly declined (Indonesian's annual per capita consumption is around 127 kilograms [3]) [4, 5]. Hence, ensuring national food self-sufficiency in the face of decreasing irrigated agricultural land areas due to massive conversion to other economic sectors is undeniably to be a major challenge for Indonesia [6-9].

At present, national rice production is mostly cultivated in irrigated rice fields (60.3\%), while the rest is produced in rain-fed paddy fields [10]. Yet a study carried out by the Center of Agriculture Data and Information System, MoA, in 2016 showed that the productivity of irrigated paddy harvested areas in Indonesia had approached a saturation point [11-13]. Besides extensification, optimization, or enhancing productivity on existing agricultural lands, particularly rainfed land is thus considered as one of the potential panaceas to address the above challenge $[14,15]$.

In the context of rain-fed paddy fields in Indonesia, there are around 3.17 million ha or $41.2 \%$ of the total wetland areas, spread over Java (34.8\%), Sumatra, Kalimantan, Sulawesi, Bali, and Nusa Tenggara [16]. Nevertheless, the contribution 
of rain-fed farming to national food production today has yet to be optimal because of its high dependency on rainfall for its irrigation. To date, planting index (PI) is low, on average only $1.0-1.05$ (planting index (PI) is the ratio of total planting area to total area available for planting crops in a year. IP of 1.05 indicates that in 100 ha land available for planting, there is 105 ha total planting area in a year). Rice farmers in rain-fed fields generally still use traditional technology, whereas irrigated rice farmers have long applied more advanced technology. Further, the international rice research community classifies rain-fed lowland areas as high-risk environments due to increasing water scarcity and climate change which threaten their vulnerability to drought, flood, or salinity $[3,10,17-20]$. A higher risk of plant pest organisms also causes farmers to be more reluctant or hesitant to apply intensive technology to rain-fed land ([14]; Lampe, 1993). Consequently, the actual farmers' yield in rain-fed fields is as low as 1.8 tons/ha [20], 3.0 - 3.5 tons/ha [21], or maximum around 4.8 tons/ha [22]. These are much lower than achievable potential yields in rain-fed areas [19]. Current research indicates that with investment on irrigation infrastructure, PI of rain-fed land can be maximized to 2-3 [11-13, 23-25]. These gaps in PI could serve as a background to boost financial and technical investments in rain-fed farming with the aim to increase sustainable production.

The key to unlock the potential contribution of rain-fed land to increase national food production is the development of water resources infrastructure, in particular rainwater harvesting facilities such as farm pond, long storage, channel reservoir, and shallow tube well. The infrastructure is required to ensure sufficient supply of irrigation water during the dry season $[23,26,27]$. In order to further improve the production capacity of food from rain-fed fields, other supporting instruments are also essential. One of these instruments is the introduction of technological innovation to rain-fed farming [28]. These interventions are expected to increase PI and trigger a shifting in the recent cropping pattern from Rice-Fallow (PI 1) to Rice-Maize/Soybean (PI 2) or Rice-Secondary crops-Secondary crops (PI 3).

The technological innovation being introduced so far covers not only cultivation aspects but also the construction of physical irrigation infrastructure as well as water management system. The integration of technical and institutional aspects in irrigation management has a positive effect on agricultural production, efficiency, and optimization of the allocation of water resources [28]. Its delivery assumes an integrated approach through Integrated Plant Management (IPM) aiming at a precision agricultural system with solid and innovative institutional support [11-13,25]. The IPM approach is participatory, site-specific, integrated, synergistic, and dynamic [29]. Studies conducted by the Indonesian Center for Rice Research (ICCR) show the multiplier effect among technological components in IPM is able to provide high yields [30]. This would lead to increased food production and income and accordingly improve the welfare of farm households [22].

This article aims to provide strategic thinking in maximizing the contribution of the currently available 4 million ha of rain-fed land to the national food production, and hence sustainable food self-sufficiency in Indonesia. The focuses of food commodities in this report are rice, maize, and soybean. The cumulative impact of the IPM approach on the rain-fed land is expected to increase national food production by $20.3 \%$ for rice, $13.1 \%$ for maize, and $180.5 \%$ for soybean, and the potential economic benefit could reach IDR 88,747 - 95,620 trillion per year. In specific, the article elaborates (i) the potential of rain-fed farming in Indonesia, (ii) policy support for promoting rain-fed farming, (iii) technological advancement for rain-fed farming in Indonesia, (iv) economic return of investment on infrastructure and technological innovation in rain-fed areas, and (v) impact of developing water management infrastructure in rain-fed fields to rice production in Indonesia.

\section{The Potential of Rain-Fed Farming in Indonesia}

Recent national statistics indicate that around 3.64 million ha of the total 7.70 million ha existing agricultural land in Indonesia is categorized as nonirrigated land, and 3.17 million ha out of which is rain-fed land [16]. Rain-fed land refers to all agricultural land whose water supply is mainly derived from rainfall and/or surface water. Therefore, irrigation of rainfed farming is largely dependent on rainfall, which makes the fields vulnerable to the risk of drought during the dry season. Rain-fed rice fields are commonly associated with or adjacent to dry land. Some of the dry lands can be converted into rain-fed paddy fields if facilitated with rain harvesting infrastructure and facilities [10].

The main crops cultivated in rain-fed areas in addition to rice are corn, soybeans, green beans, groundnuts, and horticulture crops. These plants are normally sowed during the third planting season (MK2) in irrigated rice fields or in the second and third planting seasons (MK1 and MK2) in rain-fed rice fields (the rainy season $(\mathrm{MH})$ in Indonesia starts from October to February. The dry season is then divided into the first dry season (MK1) in March-June and the second dry season (MK2) in July-September). Typically, secondary crops require water of 100-200 $\mathrm{mm} /$ month but vary according to the type and growth phase of the plant, soil pore size distribution, soil fertility level, and the required land management.

As further elaboration according to spatial data, the rainfed land in Indonesia covers around 4 million ha. It consists of 3.17 million ha of rain-fed paddy fields and 0.82 million ha of associated dried land. Out of the 3.17 million ha of rain-fed paddy fields, only 0.6 million ha are indicated to have already had water-accumulating infrastructure (WAI) and the remaining have no WAI yet including the associated dried land ([32-34], Statistics Indonesia, 2017).

The productivity and PI of rain-fed land so far are mostly highly dependent on precipitation. In the western part of Indonesia, rain-fed land is generally wet with annual precipitation $>2,000 \mathrm{~mm}$ and total 5-9 wet months (average monthly precipitation $>200 \mathrm{~mm}$ ), and dry season of fewer than 6 months (average monthly precipitation $<100 \mathrm{~mm}$ ). This enables a PI of more than one, with both paddy and 
short lifecycle of secondary crops. Meanwhile, in the eastern part of Indonesia, rain-fed land is generally dry with annual precipitation $<2,000 \mathrm{~mm}$ and a wet season of less than 5 months, and 5-10 dry months. PI in the western part of Indonesia can potentially be more than 2 , but it is currently 1.05 , or only $5 \%$ can have two plantings a year. Therefore, the potential for increasing PI in the western part of Indonesia is still relatively high. In the dry land with 5-10 dry months, PI is relatively hard to increase without any additional water sources other than rainfall $[11-13,16,35,36]$.

\section{Policy Support for Promoting Rain-Fed Farming}

Regarding the potential share of rain-fed farming to the national food production capacity, rain-fed farming forms the next mainstay of the Indonesian national food selfsufficiency program, after the irrigated farming. To maximize its contribution, an integrated intervention consisting of optimal utilization of rainwater with improved cultivation technique was supported by the Government of Indonesia (GoI) [6]. Solid support for the rain-fed farming in Indonesia appeared in 2018 when the GoI promulgated Presidential Instruction (Inpres) Number 01/2018 concerning Acceleration for the Provision of Small Farm Pond and Other Water Accumulation Infrastructure in Villages. This regulation provides legal protection for the development of irrigation infrastructure in rain-fed and dried associated paddy field ecosystem, in terms of both coordination and institutional setting. Previously, the GoI also issued regulations regarding the management of water resources as stipulated on Presidential Regulation No. 33/2011 to provide a clear guidance on the national-level management of water resources for a period of 20 years, from 2011 to 2030. This regulation and their derivative regulations address various potential problems in relation to changing in agroecosystem due to deforestation and land conversion, which affect the overall water supply for agriculture.

The construction of small farm pond and other water accumulating infrastructure are the solution to the water constraint problems of villagers for agricultural irrigation particularly during the dry season. Around $82.77 \%$ of the total 74,754 villages in Indonesia rely in terms of their livelihood exclusively on agriculture. Sustainable supply of water for irrigation all year round being facilitated through the construction of farm pond and capacity improvement of WAI is expected to increase the productivity of farm business of the villagers and trigger economic development in the villages. The optimal utilization of farm pond for irrigation can increase PI in rain-fed land from 1.0 to 3.0, and hence the income of the villagers.

\section{Technological Advancement of Rain-Fed Farming in Indonesia}

The basis of support to the rain-fed farming provided by the Government of Indonesia ultimately lies on present technological advancement available in the country. As mentioned earlier, the development of rain-fed fields in Indonesia should be carried out by establishing integrated water storage facilities with a proper water distribution system. Common infrastructure units for rainwater storage in Indonesia are farm pond, dam, and reservoir channel. The water in these units is distributed to the fields mostly by using pumping machine or utilizing gravity. Here, the use of pumping machines or channel reservoirs and farm pond in stages has been known to succeed in increasing the capacity of water and extend the coverage area of irrigation [10]. This means the PI of the field would increase and thus it would be possible to have multiple commodities which can be cultivated in a year [26, 27]. In Lombok Tengah and Lombok Timur districts, for example, the water for farming mostly flows from rain, supplemented from farm ponds. The farm ponds are generally built in an area dedicated for agriculture with the aim to improve PI from 1.0 to 2.0 or even more by planting secondary crops in the third planting season. According to the information of the Head of the Farmer Group in Jerowaru Subdistrict in Lombok Timur, the cropping pattern before a farm pond was built was only rice once a year. No other crops could be planted in the field due to lack of water sources. After a farm pond was built, the cropping pattern for a year develops into rice-rice-tobacco and rice-secondary crops-soybeans. Examples of benefits from other infrastructure in different regions of Indonesia can be seen in Table 1 .

These infrastructure units are expensive to build; hence, it is quite difficult for smallholder farmers to build one. For this reason, through Presidential Instruction (Inpres) No. 01/2018, the GoI has built 30,000 farm pond units and other water storage structures as an effort to improve the utilization of rain-fed and dryland farming. On the other hand, superior varieties of rain-fed rice have been developed and are currently ready for use. The varieties are typically tolerant of drought and disease. Among these varieties are Inpari-38 Rain-fed Rice (TH), Inpari-39 TH, and Inpari-41 $\mathrm{TH}$. The Inpari-38 TH, for example, has the potential yield of up to 8.16 tons of dried rice grain (DRG) per hectare with early maturity and more tolerant of drought. In general, the use of this variety coupled with water management technology will be able to increase rice production in rainfed farming at least $75 \%$ of current production.

These investments on infrastructure and water management system combined with the breakthrough on superior varieties of paddy were readily available for farmers to use. Nonetheless, this support alone will not guarantee the maximum contribution of rain-fed farming to the expected improvement on the national food production capacity, especially for rice, maize, and soybean. Thus, another intervention is needed in the form of suggested cultivation technique and cropping pattern which could potentially further increase productivity and PI of rain-fed farming.

With proper infrastructure and water management system, it is possible to apply multiple cropping systems per year instead of only one plant in a year. The suggested cultivation techniques are gogo rancah or to plant paddy directly from its seed, walik jerami which applies straws from previous rice crop while the soil is still wet, and super jarwo (a 
TABLE 1: Comparison of yield from annual cropping pattern in rain-fed land.

\begin{tabular}{|c|c|c|c|c|}
\hline No. & $\begin{array}{l}\text { Water Storage } \\
\text { Infrastructure }\end{array}$ & Location & Impact on PI & Attainable Benefit \\
\hline 1. & Farm pond & $\begin{array}{l}\text { Tenjolaya, Bogor, } \\
\text { Jawa Barat }\end{array}$ & $\begin{array}{l}\text { Improve PI from } 2.0 \text { to } 2.5 \\
\text { Support } 45 \text { ha }\end{array}$ & $\begin{array}{l}\text { Additional production up to } 135 \text { ton dried rice grains } \\
\text { (DRG) equal to Rp. } 500 \text { million per year }\end{array}$ \\
\hline 2. & Channel reservoirs & $\begin{array}{c}\text { Tompobulu Village, } \\
\text { Maros, Sulawesi } \\
\text { Selatan }\end{array}$ & $\begin{array}{c}\text { Paddy: improve PI from } 1.0 \\
\text { to } 2.0 \\
\text { Secondary crops: improve } \\
\text { PI from } 1.5 \text { to } 3.0 \\
\text { Support } 75 \text { ha }\end{array}$ & $\begin{array}{l}\text { Additional production up to } 1,230 \text { tons } D R G \text { equal to } \\
\text { Rp. } 4,550 \text { million per year }\end{array}$ \\
\hline 3. & Long storage & $\begin{array}{c}\text { Panyindangan Wetan } \\
\text { Village, Indramayu, } \\
\text { Jawa Barat }\end{array}$ & $\begin{array}{l}\text { Improve PI from } 2.0 \text { to } 2.5 \\
\text { Support } 900 \text { ha }\end{array}$ & $\begin{array}{l}\text { Additional production up to } 2,700 \text { tons } \mathrm{DRG} \text { equal to } \\
\text { Rp. } 9.9 \text { billion per year }\end{array}$ \\
\hline 4. & Shallow tube well & Ngawi, Jawa Timur & $\begin{array}{l}\text { Improve PI up to } 100 \% \\
\text { Support } 4 \text { ha }\end{array}$ & $\begin{array}{l}\text { Additional production up to } 6 \text { tons DRG equal to Rp. } 16 \\
\text { million per year }\end{array}$ \\
\hline
\end{tabular}

Source: Sulaiman et al. [31]; MoA [11-13]

more advanced version of jarwo technique). The gogo rancah technique will ensure that the paddy would have enough water at the time it needed the most [31]. The walik jerami, on the other hand, would improve the odds to get water for the next rice crops [37]. These two suggested cultivation techniques were known to be effective for rain-fed farming for a long time ago and could be done with minimum water harvesting and distribution infrastructure [37]. The more recent and technological is the super jarwo technique, which cannot be done without an ideal water management system. With these techniques, the suggested cropping pattern for a year which started with the rainy season $(\mathrm{MH})$ would be as follows:

paddy (with gogo rancah technique)-paddy (with walik jerami technique)-secondary crops (could be maize or soybean)

paddy (with gogo rancah and super jarwo technique)-paddy (with extended jarwo technique)-secondary crops (could be maize or soybean).

In this regard, paddy, maize, and soybean were chosen due to their priority in Indonesia food self-sufficiency target.

With the aforementioned cropping pattern, the PI for paddy would increase to 2.0 with a possibility to gain from secondary crops. In the first cropping pattern, the introduction of superior varieties (either Inpari-38 TH, Inpari-39 TH, or Inpari-41 $\mathrm{TH}$ ) using gogo rancah technique during the rainy season $(\mathrm{MH})$ could generate productivity of around 6 (six) tons of dried grain per hectare. The later paddy cropping prepared using walik jerami technique in the first dried season (MK1) would potentially result in productivity of 3.5 tons of dried grain per hectare. The potential gain from maize is five tons of dried shelled corn per hectare, or that from soybean is 1.5 tons per hectare, should these crops be planted in the second dried season (MK2) (see Table 3) [11-13, 31].

The second cropping pattern utilizes the super jarwo cultivation technique, followed with a modified ratoon technique for paddy. Different from that with regular jarwo, the super jarwo technique requires (1) high quality seed for new variety of rain-fed paddy with higher yield, (2) biodecomposer applied at land preparing stage, (3) biofertilizers as seed treatment with fair application, (4) integrated pest control technique, and (5) mechanization especially for planting and harvesting stage. The super jarwo could be applied to both irrigated rice farming and rain-fed farming. Application in rain-fed farming is done by combining it with gogo rancah technique supported by proper water harvesting infrastructure. Assuming the requirements could be attained, the following rice crop would be just an extended jarwo by ratooning the paddy. This ratoon paddy is known as jarwo plus. The jarwo plus would only yield 70\%-80\% dried grain compared to the previous rice crop (the super jarwo) [31, 38-40] but requires less time to harvest [40]. In addition, compared with the walik jerami technique, the jarwo plus would not require additional seed; thus, the cost would be cheaper.

By using the super jarwo followed by the jarwo plus, the production of rice grain during the rainy season $(\mathrm{MH})$ and first dried season (MK1) is expected to be increased. The potential yield of this cropping pattern is up to 7 tons of dried grain per hectare in $\mathrm{MH}$ and 4.5 tons per hectare in $\mathrm{MK} 1$, while the potential yield of secondary crops would be the same as that using gogo rancah and walik jerami. The comparison of annual cropping pattern for rain-fed farming is presented in Table 2 .

\section{Economic Return of Investment on Infrastructure and Technological Innovation in Rain-Fed Areas}

As mentioned before, the introduction of high quality of rain-fed paddy variety with suggested cultivation technique in the rain-fed farming with proper water harvesting and distribution system could significantly increase its PI and production [22]. However, the proper infrastructure required for water management system is expensive. Hence, it is logical to measure the economic benefit of investing in the system. In order to provide an illustration, an analysis has been made for existing infrastructure on a different type of crops (paddy, 
TABLE 2: Comparison of yield from annual cropping pattern in rain-fed land.

\begin{tabular}{lccc}
\hline Planting Index (PI) & MH (Oct-Feb) & MK1 (Mar-Jun) & MK2 (Jul-Sep) \\
\hline 3 & Gogo rancah rice & Welik jerami rice & Secondary crops \\
\hline Production Potential (Ton Dried Grain/Ha) & 6.0 & 3.5 & $\begin{array}{c}\text { Soybean: } 1.5 \\
\text { Maize: 5.0 }\end{array}$ \\
\hline 3 & Gogo rancah rice with super jarwo & Rice with jarwo plus & Secondary crops \\
\hline Production Potential (Ton Dried Grain/Ha) & 7.0 & 4.5 & $\begin{array}{c}\text { Soybean: } 1.5 \\
\text { Maize: 5.0 }\end{array}$ \\
\hline
\end{tabular}

Source: Sulaiman et al. [31]; MoA [11-13]

TABLE 3: Potential increase in crop production resulting from investment in water harvesting infrastructure.

\begin{tabular}{lccccc}
\hline \multirow{2}{*}{ Type of Infrastructure } & \multirow{2}{*}{ Coverage $(\mathrm{Ha})$} & \multirow{2}{*}{ Potential Increase of PI } & \multicolumn{2}{c}{ Potential Increase in Production (Ton) } \\
& & & Paddy & Maize & Soybean \\
\hline Channel Reservoir & 368,078 & 1.50 & $2,402,845$ & 611,666 & 217,140 \\
\hline Farm Pond & 8,535 & 0.50 & 43,665 & $-9,059$ & $-1,997$ \\
\hline Long Storage & 3,762 & 0.50 & 18,680 & $-3,562$ & -866 \\
\hline River & 113,279 & 1.00 & 643,753 & 41,259 & 19,909 \\
\hline Shallow Tube Well & 71,642 & 1.00 & 430,019 & 12,096 & 6,059 \\
\hline TOTAL & 565,296 & 1.31 & $3,538,961$ & 652,400 & 240,244 \\
\hline
\end{tabular}

Source: Sulaiman et al. [31]; MoA [11-13]

maize, and soybean) in the rain-fed field, whose result is presented in Table 3.

Table 3 was made based on improvement from the annual monocropping pattern (only paddy and only once a year) to multicropping with paddy at least twice a year. The monocropping pattern is common practice in rain-fed and dry land farming before the introduction of the Integrated Plant Management system. Table 3 indicates that, currently, the total area for rain-fed or dry land farming supported by water management system is 0.56 million ha. Most used infrastructure is channel reservoir, which covers 368,078 ha $(65 \%)$ of the area. With this facility, the increment in production for paddy, maize, and soybean is up to 2.4 million tons, 0.6 million tons, and 0.2 million tons, respectively. A different result is apparent for the infrastructure types of the farm pond and long storage. The improvement in PI decreases the production of maize and soybean, but it is being compensated for by an increase in production of paddy. In total, the 0.56 million ha of rain-fed areas have been improved by building water management infrastructure with average gains in PI equal to 1.31. The total additional production of paddy, maize, and soybean would be as large as 3.5 million tons, 0.6 million tons and 0.2 million tons, respectively.

Should we capitalize the potential gains yielded from building various infrastructures as figured in Table 3, one will realize the economic return of investment of those buildings. In this case, we will use the cost of investment on these infrastructures as stated in Sulaiman et al. [31] study, i.e. (a) channel reservoir would cost us as much as Rp. 4.5 million per ha, (b) farm pond cost is Rp. 4 million/ha, (c) long storage cost is Rp. 4 million/ha, (d) optimization of river flows cost is Rp. 5.95 million/ha, and (e) building shallow tube well would cost us Rp. 5.4 million/ha. As for the profit in the matter, we will convert the gain in production in Table 3 to the value of the product in Indonesian local market. In this context, we will use the average price of the commodities in 2017 in the province where the infrastructure was built. The result of this analysis was shown in Table 4 for paddy-paddy-maize and paddy-paddy-soybean cropping pattern.

From the table and by using predefined analysis method, we have learned that improving PI in the rain-fed area would benefit us at least Rp. 19,517,318 million with cropping pattern paddy-paddy-soybean. With paddy-paddy-maize, we would have a net profit estimated up to Rp. 20,198,679 million. If we look at the profit for each type of infrastructure, the channel reservoir for the first cropping pattern would give us the larger economic profit by Rp. 39 million per ha field it supports. These figures are achievable by applying all previously mentioned technological advancement.

\section{Impact of Developing Water Management Infrastructure in Rain-Fed Fields on Rice Production in Indonesia}

Previous illustration of potential gain in rice production (Table 3) and its economic benefit (Table 4) were made by observing the existing water harvesting infrastructure types in rain-fed fields with total coverage of 565,296 ha. This area covers only $14 \%$ of total rain-fed and associated dry land in the country that accounted for almost 4 million ha. There are 824,008 ha of associated dry land and 2,610,146 ha of rain-fed land, which have yet to had water management infrastructure. Since the associated dry land would normally cover an area adjacent to the rain-fed field, one could assume that the land requires the same water management facilities as the bordering rain-fed field. Table 5 shows the potential increase in production should the GoI develop the rain-fed 
TABLE 4: Potential economic return from investment on water harvesting infrastructure.

\begin{tabular}{|c|c|c|c|c|}
\hline Type of Infrastructure & Coverage $(\mathrm{Ha})$ & $\begin{array}{l}\text { Potential Income } \\
\text { (IDR million) }\end{array}$ & $\begin{array}{c}\text { Cost } \\
\text { (IDR million) }\end{array}$ & $\begin{array}{c}\text { Economic Profit } \\
\text { (IDR million) }\end{array}$ \\
\hline \multicolumn{5}{|c|}{ Cropping Pattern: Paddy - Paddy - Maize } \\
\hline Channel Reservoir & 368,078 & $16,021,758$ & $1,656,352$ & $14,365,406$ \\
\hline Farm Pond & 8,535 & 168,669 & 34,141 & 175,955 \\
\hline Long Storage & 3,762 & 70,977 & 286,566 & 69,965 \\
\hline River & 113,279 & $3,028,504$ & 453,117 & $3,395,609$ \\
\hline Shallow Tube Well & 71,642 & $1,982,038$ & 286,566 & $2,191,744$ \\
\hline TOTAL & 565,296 & $21,271,946$ & $2,716,743$ & $20,198,679$ \\
\hline \multicolumn{5}{|c|}{ Cropping Pattern: Paddy - Paddy - Soybean } \\
\hline Channel Reservoir & 368,078 & $15,313,272$ & $1,656,352$ & $13,656,919$ \\
\hline Farm Pond & 8,535 & 188,420 & 34,141 & 196,571 \\
\hline Long Storage & 3,762 & 77,823 & 286,566 & 77,905 \\
\hline River & 113,279 & $3,007,181$ & 453,117 & $3,393,847$ \\
\hline Shallow Tube Well & 71,642 & $1,978,634$ & 286,566 & $2,192,075$ \\
\hline TOTAL & 565,296 & $20,565,329$ & $2,716,743$ & $19,517,318$ \\
\hline
\end{tabular}

Source: Sulaiman et al. [31]; MoA [11-13]

TABLE 5: Potential increase in crops production resulting from rain-fed fields WITH and WITHOUT investment in water harvesting infrastructure.

\begin{tabular}{lccc}
\hline Type of Infrastructure & Coverage Areas (Ha) & \multicolumn{2}{c}{ Potential Increase in Production (Ton) } \\
Maize
\end{tabular}

Source: Sulaiman et al. [31]; MoA [11-13]

and dry land field for paddy, maize, and soybean. The table uses the information in Table 3 with an addition to associated dry land. The potential of remaining rain-fed and dry land without water harvesting infrastructure was estimated if there is an improvement in cultivation technique (gogo rancah and walik jerami) and usage of superior rain-fed crops varieties.

Further, Table 5 indicates that in aggregate, development of nearly 4 million ha of rain-fed and dried-associated land, with and without investment on water harvesting infrastructure, generated additional production of around 16.7 million tons of dried grain per hectare, 3.7 million tons of dried shelled corn, and 0.98 million tons of soybeans. In terms of rice, investment in water infrastructure contributed around $41 \%$ to the total gain, while the remaining $59 \%$ was generated from the rain-fed land whose potencies for irrigation infrastructure services are not yet being identified.
Another potential benefit from water accumulating infrastructures is through the practice of freshwater fish farming. In addition, well-designed water accumulating infrastructure such as farm ponds and dams can provide an artistic landmark and tourist attraction in the location, which generates other potencies of additional income for farm households.

\section{Conclusion}

Rain-fed farming is a potential solution to address the challenge of ensuring national food self-sufficiency in the face of decreasing irrigated agricultural land areas due to massive conversion to industrial use and housing. An integrated intervention involving technology breakthrough and innovation 
in cultivation technique has been observed to be the key to its optimal utilization. The technology used in constructing a water management system and generating superior crops variety is able to withstand the low level of water condition. The cultivation techniques suggested for rain-fed farming are gogo rancah, walikjerami, super jarwo, and ratoon paddy. The suggested cropping pattern is paddy-paddy-maize or paddypaddy-soybean.

These interventions, which have been applied to the existing rain-fed fields in Indonesia, which covers only 0.57 million ha or $14 \%$ of total rain-fed fields and associated dry land, have been proven to be quite valuable. The fields are observed to have a return of investment up to Rp. 20,198,679 million or at least Rp. 19,517,318 million. In addition, the development of rain-fed and associated dry land farming would also boost the food production capacity in Indonesia. An intervention on 4 million ha of rain-fed land is estimated to increase annual rice production by 16.7 million tons. The production of maize and soybean is also expected to increase by 3.7 million tons and 0.98 million tons per year, respectively.

This study provided a strategy to optimize the production of rain-fed fields with additional evidence of its significant economic value. The perspective used in this study solely focuses on production and economic gain without considering the benefit felt by rain-fed smallholder farmers. A similar study with farmers as its focus will contribute further to the rain-fed farming development in Indonesia. Moreover, the capacity of Indonesian institutions toward rain-fed farming could also be an interesting topic of future study, which will enhance deeper understanding of rain-fed development in the country.

\section{Conflicts of Interest}

The authors declare that they have no conflicts of interest.

\section{References}

[1] FAO, "The future of food and agriculture - Trends and challenges," 2017, http://www.fao.org/3/a-i6583e.pdf.

[2] United Nations, "World populations prospects revision," 2018, https://population.un.org/wpp/.

[3] IRRI, "In Indonesia: Experts discuss strategy for adopting a web-based app for climate prediction in rainfed rice areas," 2016, http://news.irri.org/2016/08/in-indonesia-experts-discussstrategy.html.

[4] Statistics Indonesia, "Rata-Rata Konsumsi per Kapita Seminggu Beberapa Macam Bahan Makanan Penting, 2007-2017," 2018, https://www.bps.go.id/statictable/2014/09/08/950/rata-ratakonsumsi-per-kapita-seminggu-beberapa-macam-bahan-makanan-penting-2007-2017.html.

[5] Ricepedia, “The global staple," 2019, http://ricepedia.org/riceas-food/the-global-staple-rice-consumers.

[6] Ministry of Agriculture (MoA), "Rencana Strategis Kementerian Pertanian Tahun 2015-2019/Strategic Planning of Ministry of Agriculture 2015-2019," Jakarta, Indonesia, Biro Perencanaan/Bureau of Planning, 2015.

[7] S. A. Djalil, "Arah Kebijakan Rencana Kerja Pembangunan Tahun 2017/Policy Direction for National Development Plan
2017,' Menteri Perencanaan Pembangunan Nasional/Minister of National Development Planning, Paper presented in South Kalimantan, Banjarmasin, 2016.

[8] A. Mulyani, N. D. Suharta, Kuncoro., and Z. Abidin, "Identifikasi karakteristik potensi lahan sawah untuk peningkatan dan pengembangan IP-400/Identification of characteristics of agricultural land potencies to increase and develop IP-400," Bogor, Indonesia, Balai Besar Litbang Sumberdaya Lahan, 2011.

[9] S. Ritung, I. Las, and I. Amien, "Kebutuhan lahan sawah untuk kecukupan produksi bahan pangan periode 2010 - 2050/The need of agricultural land for food production sufficiency 20102050," Jakarta, Indonesia, IAARD Press, 2010.

[10] A. A. Sulaiman, S. Kasdi, I. Las et al., "Membangkitkan empat juta hektar lahan sawah tadah hujan: Mendukung swasembada pangan berkelanjutan," Jakarta, IAARD Press, 2018.

[11] MoA, "Statistik Pertanian 2017/Agricultural Statistics 2017," Jakarta, Indonesia, Pusat Data dan Informasi/Center for Agricultural Statistics, 2017.

[12] MoA, "Petunjuk Teknis Implementasi Infrastruktur Panen Air/Technical Guidance for the Implementation of Water Harvesting Infrastructure," Jakarta, Indonesia, Badan Litbang Pertanian/Indonesian Agency for Agricultural Research and Development, pp. 37, 2017.

[13] MoA, "Outlook Komoditas Pertanian Subsektor Tanaman Pangan,” Padi, 2017, http://epublikasi.setjen.pertanian.go.id/arsipoutlook/81-outlook-tanaman-pangan/433-outlook-padi-2016.

[14] A. A. Boling, "Yield constraint analysis of rain-fed lowland rice in Southeast Asia," Wageningen, Netherlands, p. 140, 2017.

[15] S. N. Sukarman, "Kebutuhan Lahan Kering untuk Kecukupan Produksi Bahan Pangan Periode 2010 - 2050/Needs of Dried Land for Food stuff Production Sufficiency," Jakarta, Indonesia, IAARD Press, 2010.

[16] MoA, "Statistik Pertanian 2018/Agricultural Statistics 2018," Jakarta, Indonesia, Pusat Data dan Informasi/Center for Agricultural Statistics, 2018.

[17] D. J. Mackill, Rainfed Lowland Rice Improvement, IRRI, Manila, Philippines, 1996.

[18] R. Lal and B. Stewart, Eds., World Soil Resources and Food Security, CRC Press, Boca Raton, Fla, USA, 2012.

[19] S. P. Wani, J. Rockström, and T. Y. Oweis, Rainfed Agriculture: Unlocking The Potential, vol. 7, CABI, Oxfordshire, UK, 2009.

[20] H. Pane, A. Wihardjaka, and A. M. Fagi, "Menggali potensi produksi padi sawah tadah hujan," in Paddy Book 2, A. A. Daradjat, A. Setyono, A. K. Karim, and A. Hasanuddin, Eds., vol. 2, pp. 201-221, 2009.

[21] D. H. M. T. Widyantoro, "Optimalisasi pengelolaan padi sawah tadah hujan melalui pendekatan pengelolaan tanaman terpadu," Pros. Pekan Serealia Nasional, pp. 648-657, 2010.

[22] L. S. M. Indah, W. A. Zakaria, and F. E. Prasmatiwi, "Analisis efisiensi produksi dan pendapatan usaha tani padi sawah pada lahan irigasi teknis dan lahan tadah hujan di Kabupaten Lampung Selatan/Efficiency analysis of production and income of rice farming business on technically irrigated and rain-fed land," Journal of The Indian Institute of Architects, vol. 3, no. 3, pp. 228-234, 2015.

[23] S. Faimah, K. Ramija, and A. dan Mulyani, "Pompa air menjadi titik ungkit Indeks Pertanaman (IP) 300 padi sawah tadah hujan/Water pumping as leverage point for Planting Index," Warta Penelitian dan Pengembangan Pertanian, vol. 39, no. 6, 2017. 
[24] N. Heryani, G. Irianto, and N. Pujilestari, "Pemanenan air untuk menciptakan sistem usaha tani yang berkelanjutan/Water harvesting to create sustainable farm business system," Buletin Agronomi, no. 2, pp. 45-52, 2002.

[25] G. Irianto, "Kebijakan dan program pengembangan infrastruktur panen air di lahan pertanian/Policy and program on development of water harvesting infrastructure in agricultural land," Paper presented in TOT on Identification and Water Harvesting Infrastructure Design to Improve IP, Bogor, November 2016.

[26] N. Pujilestari, G. Irianto, and N. Heryani, "Peningkatan produktivitas lahan kering melalui pembangunan channel reservasi bertingkat/Increasing dried land productivity through layered channel reservoir," Paper presented in National Seminar Puslitbangtanak, Cisarua - Bogor, 2002.

[27] N. Heriyani, H. Setiawan, and S. H. Adi, "Penilaian kesesuaian pembangunan dam parit bertingkat untuk antisipasi kekeringan/Assessment of the suitability of layered channel reservoir to anticipate drought: Studi Kasus di Kecamatan Cenrana," Kabupaten Maros, Provinsi Sulawesi Selatan, Sumber Daya Air, vol. 9, no. 1, 2013.

[28] B. Rachman and K. Kariyasa, "Dinamika kelembagaan pengelolaan air irigasi/Institutional dynamics of irrigation water management," Bogor, Indonesia, Pusat Penelitian dan Pengembangan Sosial Ekonomi Pertanian, 2002.

[29] Z. Zaini, S. N. Abdurrahman, N. Widiarta et al., "Pedoman umum PTT padi sawah/General guidance for Integrated Plant Management on paddy wetland," Jakarta, Indonesia, IAARD Press, 2009.

[30] Balitpa, "Pengkajian dan pengembangan intensifikasi padi lahan irigasi berdasar pengelolaan tanaman dan sumber daya terpadu," Sukamandi, Indonesia, Balitpa, 2000.

[31] A. A. Sulaiman, B. I. Setiawan, K. Subagyono et al., Panen Air Menuai Kesejahteraan Petani/Water Harvesting for Farmers' Welfare, A. M. Fagi and I. Las, Eds., Sekretariat Jenderal, Kementerian Pertanian, Jakarta, Indonesia, 2017.

[32] Statistics Indonesia, "Proyeksi penduduk Indonesia 20102035/Projection of Indonesian Population 2010-2035,” Jakarta, Indonesia, Badan Pusat Statistik (BPS), 2013.

[33] Statistics Indonesia, "Statistik 70 tahun Indonesia merdeka/ Statistics 70 year Indonesian independence," Jakarta, Indonesia, Badan Pusat Statistik (BPS), 2015.

[34] Statistics Indonesia, "Indonesia dalam angka 2017/Indonesia in figures 2017," Jakarta, Indonesia, Badan Pusat Statistik (BPS), 2016.

[35] C. J. Jayatilaka, R. Sakthivadivel, Y. Shinogi, I. W. Makin, and P. Witharana, "A simple water balance modelling approach for determining water availability in an irrigation tank cascade system," Journal of Hydrology, vol. 273, no. 1-4, pp. 81-102, 2003.

[36] MoA, "Statistik Pertanian 2016/Agricultural Statistics 2016," Jakarta, Indonesia, Pusat Data dan Informasi/Center for Agricultural Statistics, 2016.

[37] IRRI, "Rainfed lowland rice," in Proceedings of the 1978 International Rice Research Conference, 1979.

[38] F. C. Oad, S. Cruz, N. Pompe, N. L. Memom, and O. S. ZiaUl-Hassan, "Rice ratooning management," Journal of Applied Sciences, vol. 2, no. 1, pp. 29-35, 2002.

[39] IAEA, "Rice fields in China double yields by ratooning," 2018, https://www.iaea.org/newscenter/news/rice-fields-in-chinadouble-yields-by-ratooning.

[40] IRRI, Rice Ratooning, IRRI, Los Banos, the Philippines, 1988. 


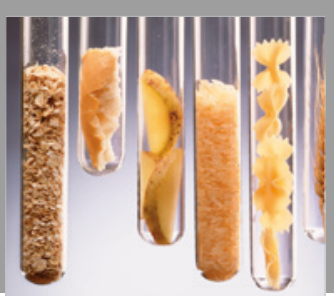

International Journal of Food Science

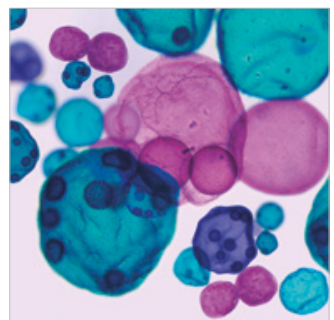

International Journal of Microbiology
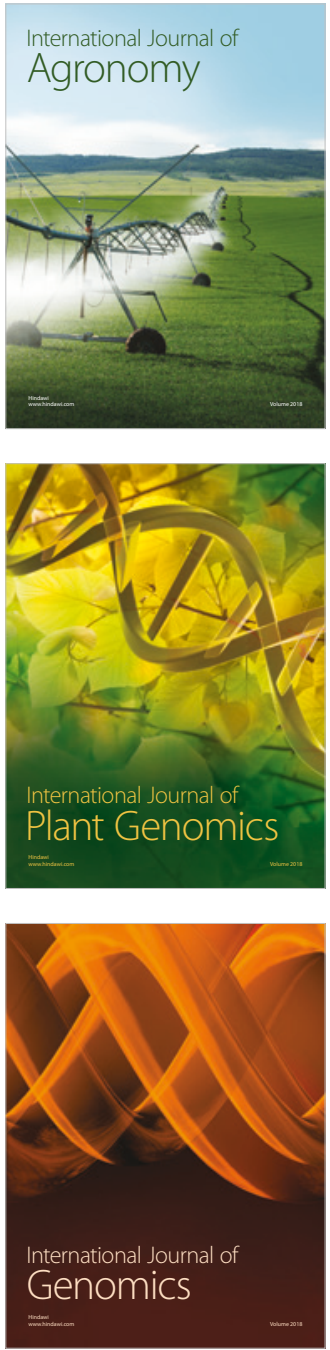

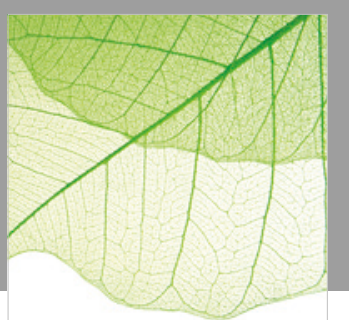

Journal of Botany
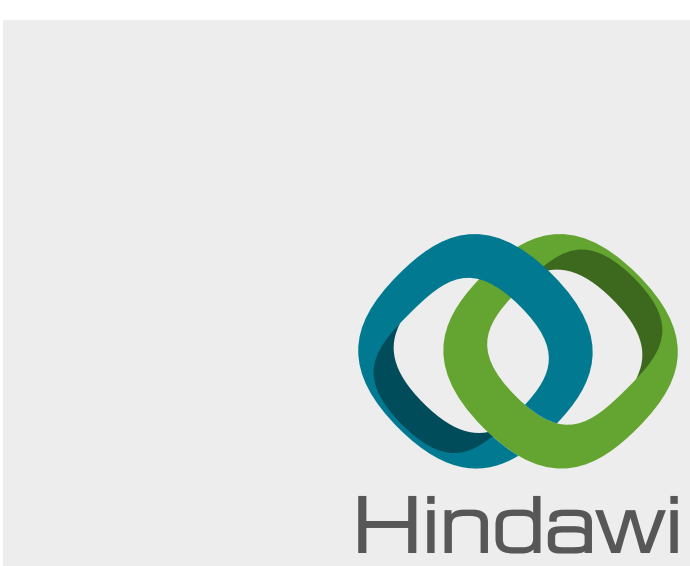

Submit your manuscripts at

www.hindawi.com
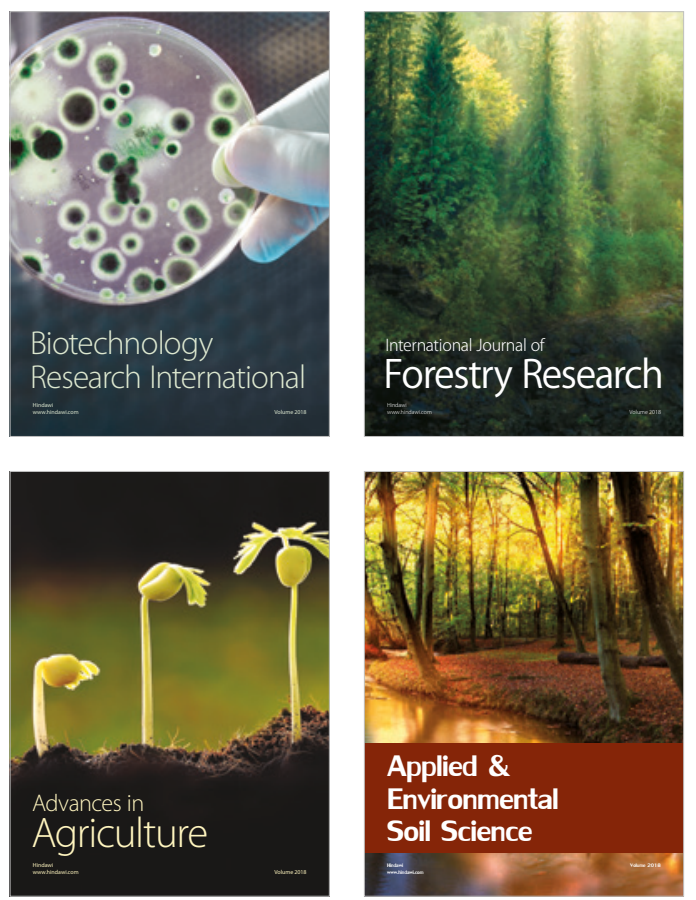

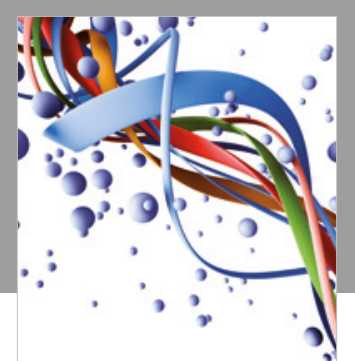

Scientifica

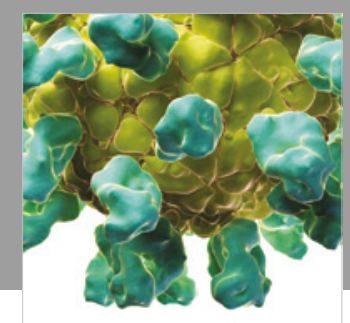

Veterinary Medicine International

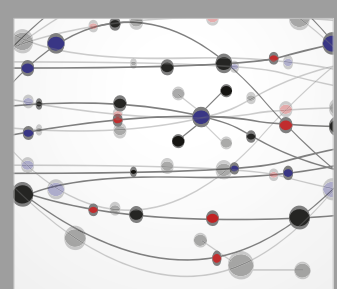

The Scientific World Journal
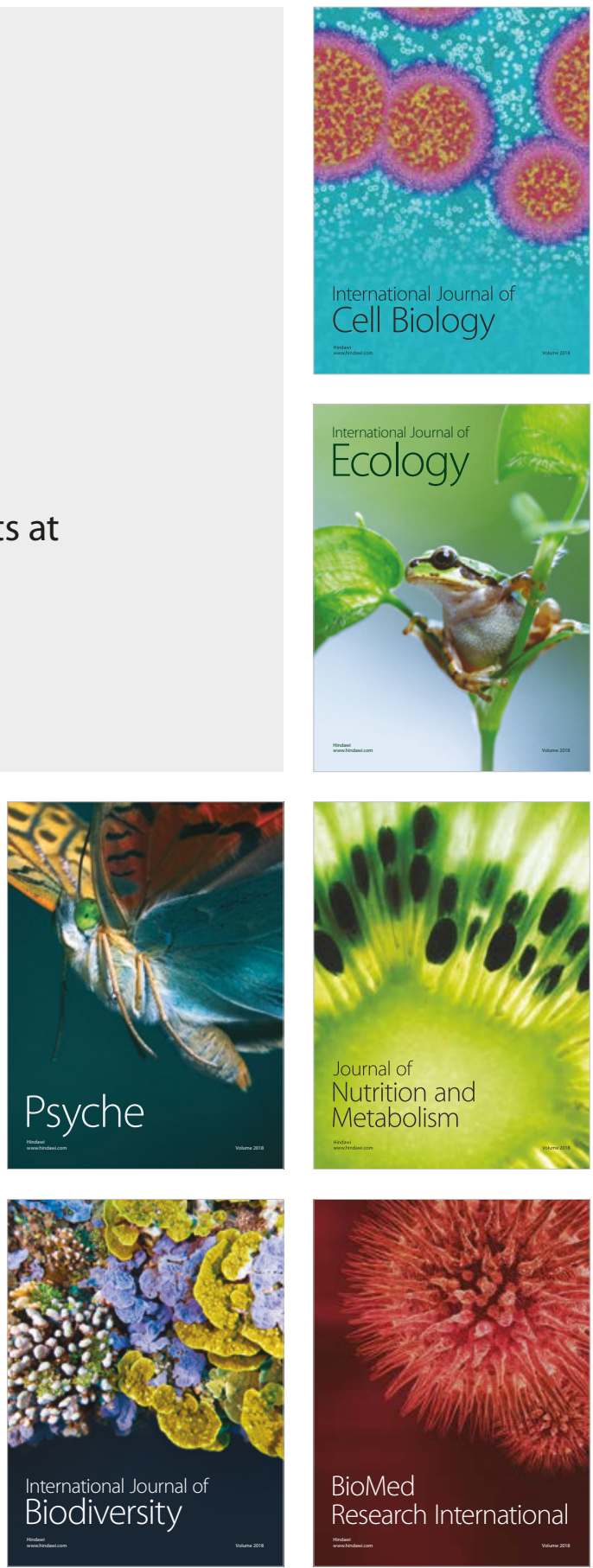